العـــــــد السـابع والثلاثون

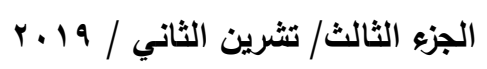

جامعة واسط

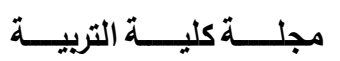

\title{
تحوّلات تقديم المُسندِ إليه في الدرس البلاغي
}

أ.م. د ميثم قيس مطلك الزبيدي

جامعة القادسية / كلية التربية

الإيميل Maythem232@gmail.com

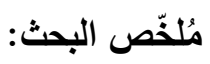

اتِّهت عناية البحث النحوي إلى دراسة الجملة على وفق ما يقضيه النظام اللغوي، في حين اتجّهت عناية البحث البلاغي إلى دراسة الاعتبارات أو المزايا التي ولّدها العدول عن أصل ذلك النظام ، وهو أمر مُرتبط بملابسات القول ارتباطًا مباشرًا. ومن هنا اعتنى هذا البحث بدراسة تحوّلات تقديم المسند إليه بلحاظ تلك الاعتبارات، وبالاتكاء على مقولة (التحوّل) أو (التّحويل) التي ترجع إلى اللغوي الأمريكي نعوم نشومسكي وجهوده في البحث اللساني. وهذهِ المقولة أو ما يُعرف بـ(المنهج التحويلي) ينظر إلى مبنى الجمل باعتبارين، أولهما: مبنى ظاهري يُمتّل الشكل الخارجي للجملة بترتيب الكلمات على نمط مُعيّن، وهذا المبنى يُعرف بـ(البنية السطحية)، وثانيهما: مبنى باطني يُمنّل العمليات العقلية العميقة التي لا مناص من فهمها لمعرفة الطبيعة الخلّاقة في اللغة، وهذا المبنى يُعرف بالبنية العميقة)(')، وكل سطح كلامي هو نتاج تلك العمليات العقلية؛ أي أنَّه يرتّ إلى بنية عميقة هي البنية الأصل، وهذا يفيد في أنّ البلاغيين كانوا مدركين أنّ المسند إليه نطرأ عليه مجموعة من التحوّلات، والتقديم واحدُ من نلك التحوّلات، بل هو أهمها؛ ولنلك يذهب الدكتور محمد عبد المطلب إلى أنّ البحث البلاغي انطلق من مفهوم تحويلي دقيق، وإنْ لم يذكره البلاغيون بمصطلحه الحديث، لكنّهم كانوا على وعي بـ(r). 


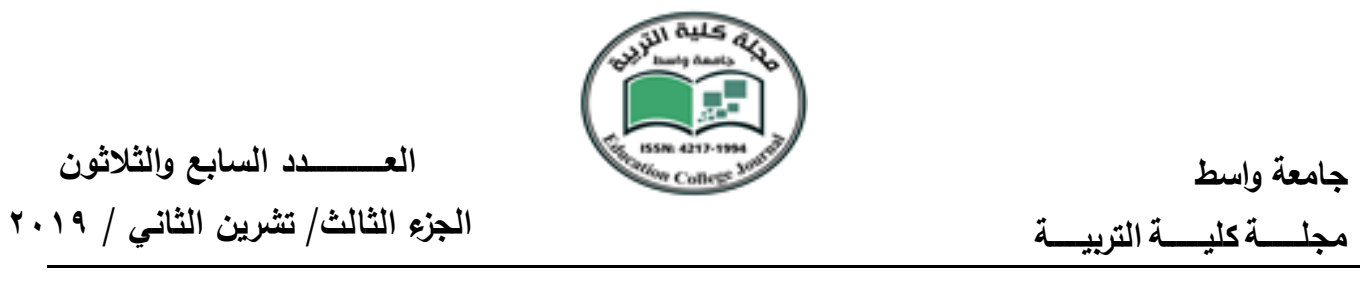

Transformations of the assignee in the rhetorical lesson

\section{Dr. Maitham Qais Mutlaq}

University of Qadisiyah \Faculty of Education

Email : $\underline{\text { Maythem232@gmail.com }}$

Abstract:

The attention of grammatical research was to study the sentence as required by the linguistic system, while the attention of rhetorical research was to examine the considerations or advantages generated by the descent from the origin of that system, which is directly related to the circumstances of the statement. Hence, this study is concerned with the study of the shifts in the presentation of the subject, in the light of these considerations, and by relying on the saying "transformation" or "conversion", which refers to the American linguist Noam Chomsky And his efforts in linguistic research. The first is a virtual building that represents the outer shape of the sentence in the order of words in a certain pattern. This structure is known as the surface structure, and the second is a mystical building that represents the deep mental processes that inevitably follow. From its understanding of the creative nature of the language, this building is known as the "deep structure", And every surface of my speech is the product of those mental processes; that is, it returns to a deep structure is the structure of origin, and this indicates that the Plagyans were aware that the subject to him a set of transformations, and submission of one of these transformations, but the most important; Mohammed Abdul Muttalib that the rhetorical search was launched from the concept of accurate conversion, although not mentioned Balagheon modern terminology, but they were aware of it. 
العـــــــــد السابع والثلاثون

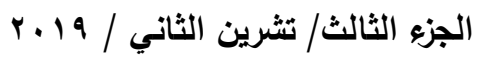

تُعدّ اللغة العربية واحدة من اللغات المعربة التي امتازت بمرونة التركيب، وأخذت الكلمة فيها قرًا من حريّة الحركة، فمن شأن الإعراب أنْ يُسهر إسهامًا فاعلًا في تبيّن الدَّلالة، وإنْ اختلفت مواقع

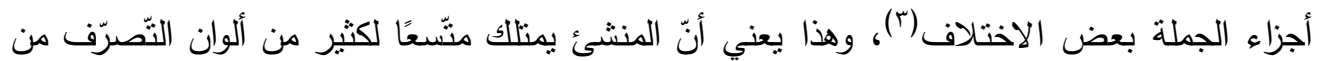
دون أنْ يخشى الوقوع في اللّبس، أو الإخلال بمقاصد الكلام (ع).

فالتقديم والتأخير - إذًا - لون من ألوان حرِّة هذهِ اللغة وخصيصة من خصائصها(0)، وقد التقت البلاغيون إلى أهمية هذا الباب والمكانة التي يشغلها، يقول عبد القاهر الجرجاني في التقديم والتأخير :

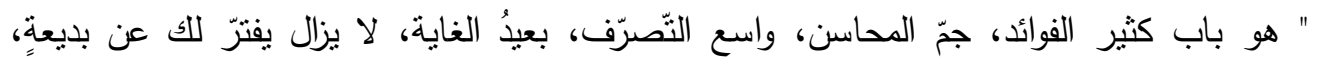
ويُفضي بك إلى لطيفةٍ، ولا نزال ترى شعرًا يروقلك مسمعه، ويلطف لديك موقعه، ثُّم تتظر فتجد سبب

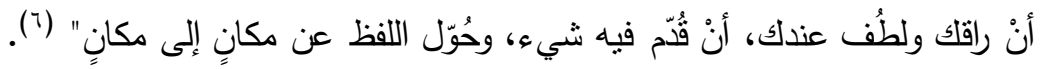
ويُّلاحظ في التقديم والتأخير أنّه بأخذٌ حركة تحوّلية داخل نظام الجملة؛ أي أنَّ التحوّل يبرز في البنية السطحية بانتقال الدّال من موضعه الأصلي إلى موضع طارئ في الخط الامتذادي والأفقي

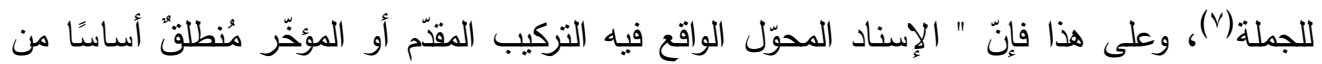
فهم الأحوال المتحوّلة والمتغيرة للخطاب"(^).

وينبغي الالتفات إلى أنّ التصرّف في البناء النحوي للجملة لا يعني بأيَّة حالٍ من الأحوال " مُخالفة

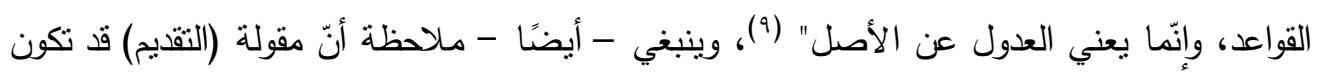
خالصة للبعد المعنوي؛ نلك أنّ المسند إليه محكوم عليه، والمحكوم عليه هو الذّي يخطر في الذهن؛ أي منقدم في الذهن على المحكوم به؛ بمعنى أنّ هذهِ المقولة لا تكتسب حقيقتها الخالصة إذا كان المُسند إليه يشُخل موقع الفاعلية؛ لأنّ موضعه الدّائم هو التأخّر عن الفعل، ومن ثمّ تتبّهه مقولة

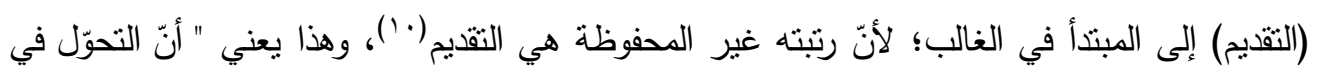
التقديم والتأخير يأخذ طبيعة ذهنيّة بالذّرجة الأولى" (''). ولعلّ هذا الإدراك هو الّذي حدا عبد القاهر على تقربع التقديم على وجهتين:

الوجهة الألّى: تقديم على نيّة التأخير(r')، ويُسمى بالتحويل المحلّي (r')، وهذا يتّضح في كلّ شيء أقررته - مع التقديم - على حكمه الّّي كان عليه، وفي جنسه الّّي كان فيه، كما في 
العـــــــــد السـابع والثلاثون

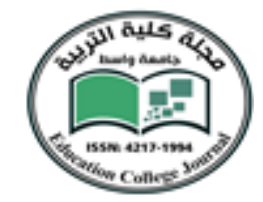

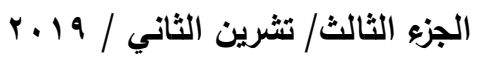

جامعة واسط

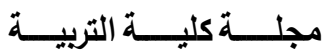

خبر المبندأ، والمفعول إذا قدّمته على الفاعل كما في قوللك :(منطلقُ زيدّ) و (ضربَّ عمرًا زيدٌ)،

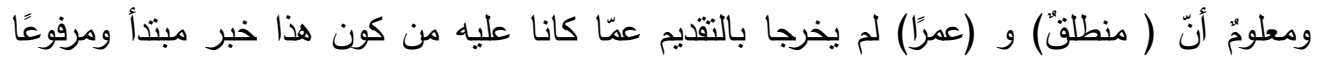

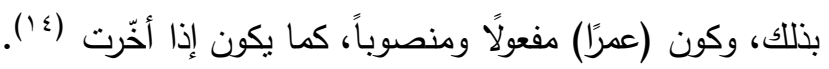

الوجهة الثانيّة: تقديم لا على نيّة التأخير (10)، ويُسمى بالتّحويل الجذري(1')، وهو أنْ يُنقل

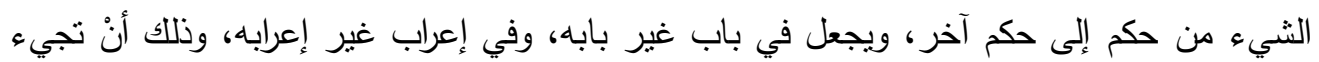

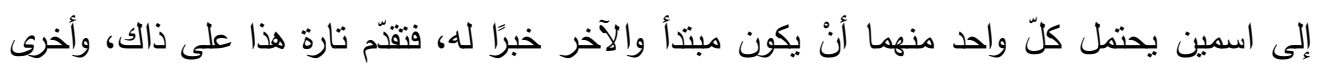

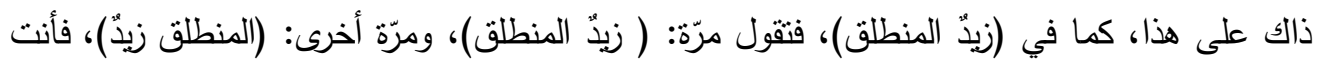

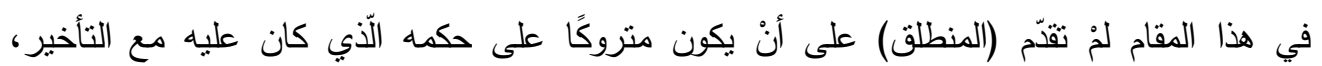

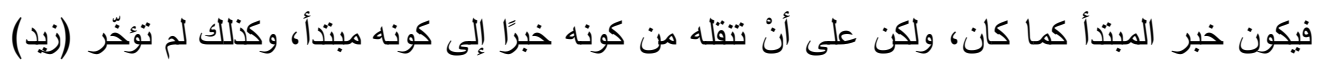

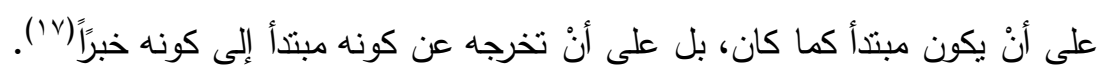

إنّ التحوّل في المُسند إليه بالتقديم يُمنّل اهتزازًا في الصياغة بأكلها؛ ذلك أنَّ تقديم المسند إليه

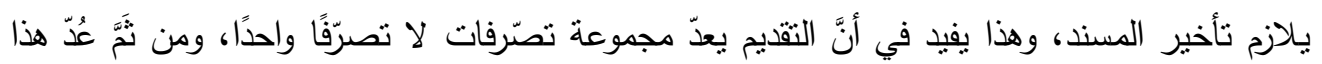

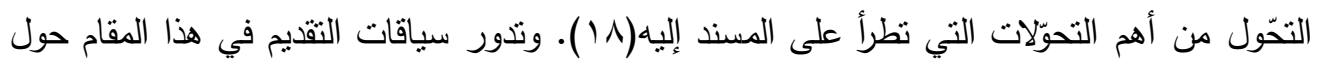

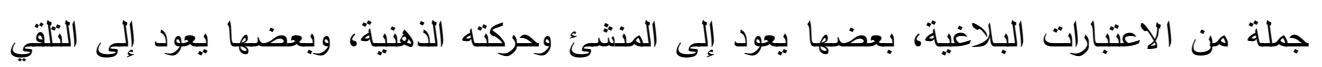

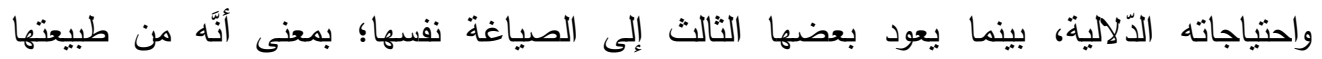
المثناليّة (9) (19).

الاعتبارات أو الأغراض البلاغية التي ينتجها هذا التحّول:

- أنْ يكون المسند إليه هو الأصل:

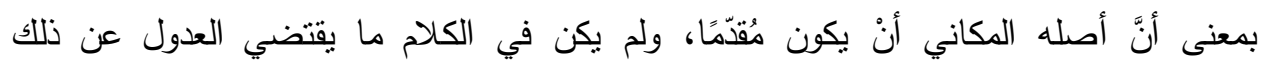

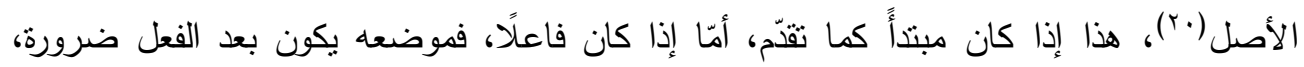

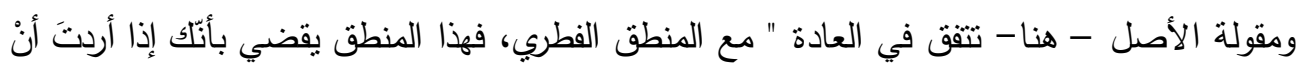

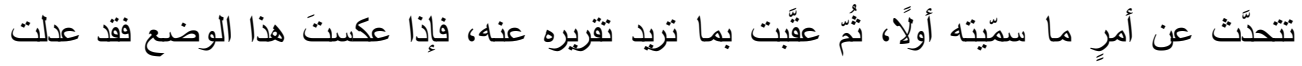

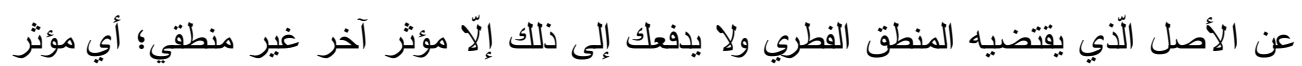

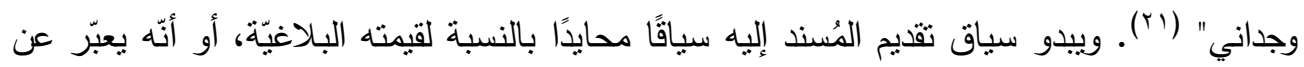


العـــــــــد السـابع والثلاثون

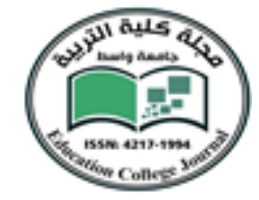

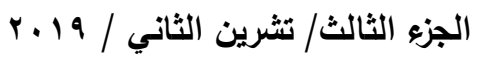

جامعة واسط

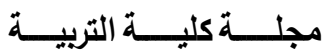

البنية المحايدة التي تتطلق منها التحوّلات؛ ولذلك اشترط البلاغيون عدم اقترانه بما يوجب العدول

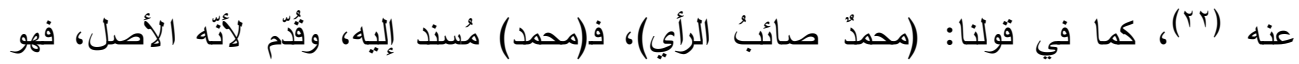

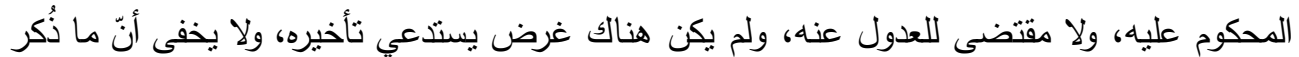

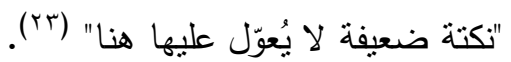

\section{- - - - مأنْ يكون في المسند إليه تشويق إلى المسند}

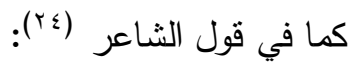

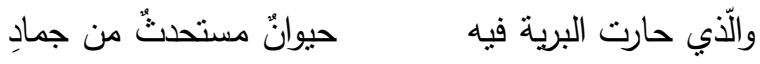

فالثاهد فيه هو تقديم المسند إليه (والّذب)؛ ليمكّن الخبر (حيوانٌ..) في ذهن المتلقي، ومدار ذلك التكّن على أنَّ صلة المبندأ (حارت البرية فيه) تنثير في النفس الدهشة والعجب والتساؤل عن هذا

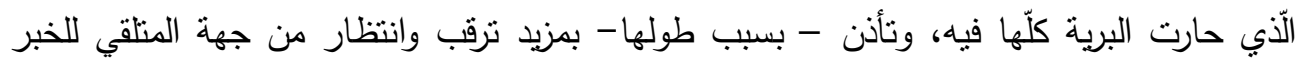

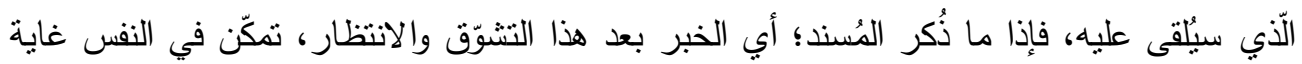
التكّّن واستثرّ في القلب غاية الاستقرار (ror).

ويذهب أحد الباحثين إلى أنّ هذهِ الإنتاجية تعتدد على طبيعة المضمون إذا كان له أهيّة من

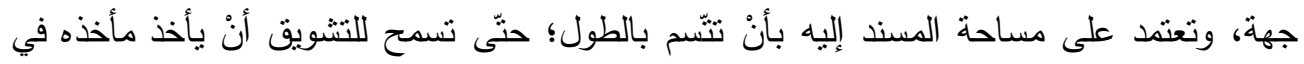

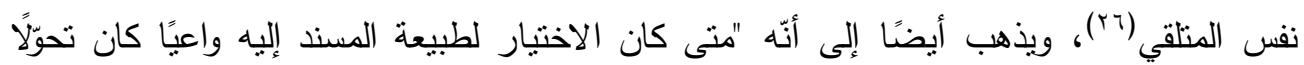

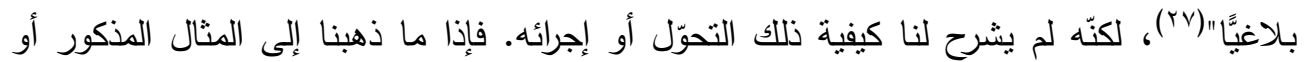
الثاهد في البيت السابق لوجدنا أنَّ المُسند إليه مقّم والمُسند مؤخر ، وهذا هو حال الجملة الأصل

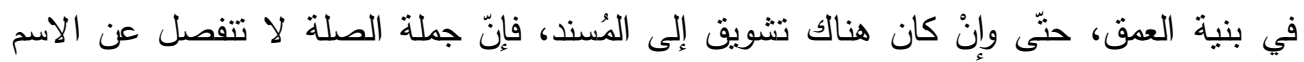

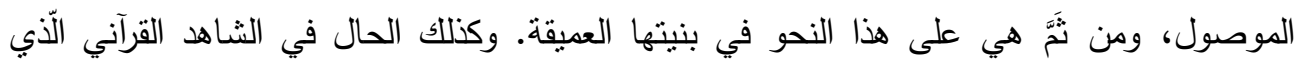
تمثتل به ذللك الباحث، وهو قوله تعالى

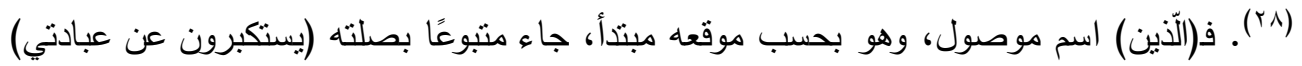

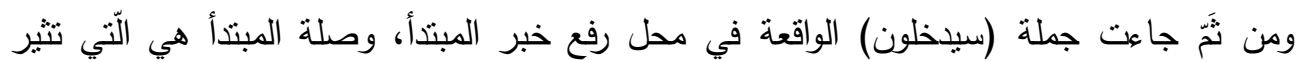

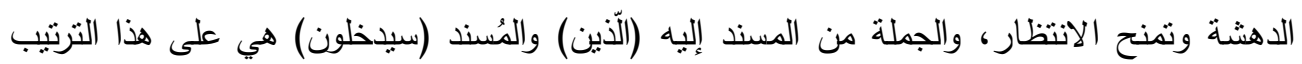

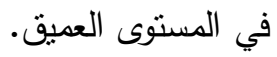


العـــــــــد السـابع والثلاثون

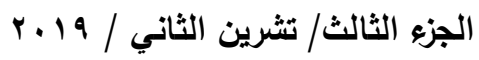

جامعة واسط

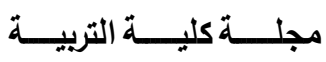

- أن تكون الصياغة توقيفيّة لإنتاج معنى معيّن:

وهنا ممّا يُرى تقديم الاسم فيه كاللّزم كما في (منل) و (غير)، فيلزم تقديمهما إذا قُصد بهما الكناية

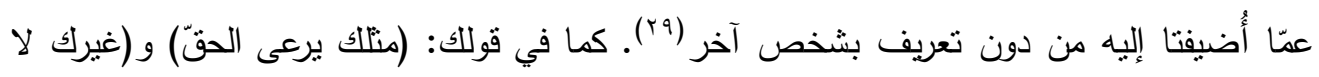

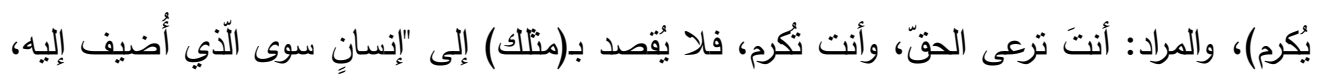

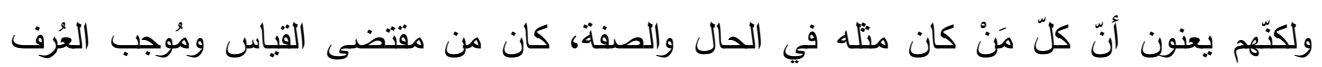

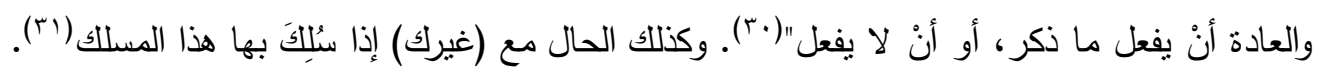
وتقديم (متل وغير) إنّما يكون تقديمًا لازمًا؛ ذللك أنّ الكناية أبلغ من التصريح وآكد، فهي كدعوى لتهي الثيء مصحوبًا بالتّليل ومشفوعًا بالبينّة، والدعوى الدصحوبة بدليلها أقوى وآكد من تلك المرسلة

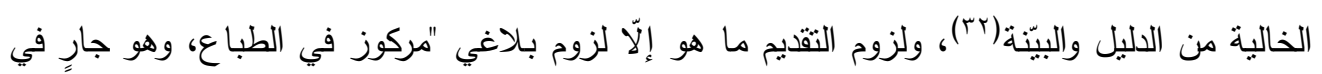

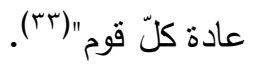

ويرى أحد الدّارسين أنَّ التحليل البلاغي لهذهِ الظاهرة يتضح في " أنّ المتكلّم يؤسس عملية

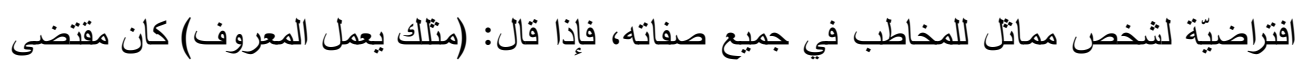

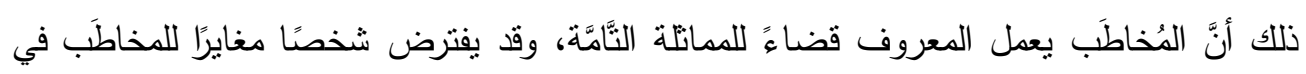
تمام الصفات، فإذا قال: (غيرك يكنب) كان مقتضاه أنّ المخاطب لا يكنب قضاءً للمغايرة

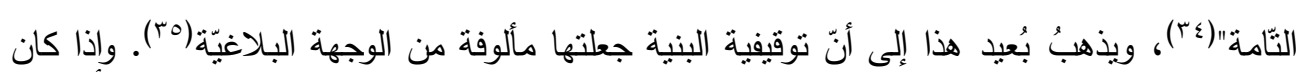

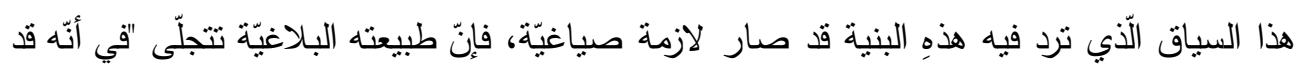

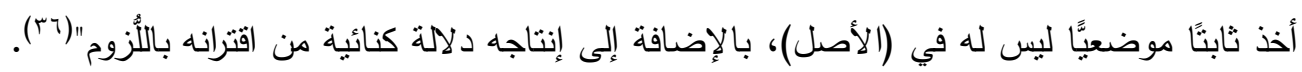
وعليه يُمكن إجراء التحوّل البلاغي على هذهِ البنية على النحو الآتي: 
العـــــــد السـابع والثلاثون

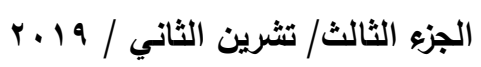

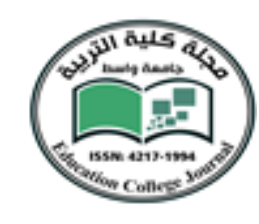

جامعة واسط

مجلـــــة كليـــــة التربيـــــة

بنية العمق أنتَ تعمل المعروف

(منل)

النحوّل البلاغي

$\downarrow$

منتلك يعمل المعروف

بنيّة السطح

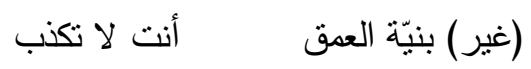

$\downarrow$

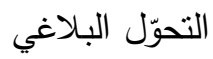

$\downarrow$

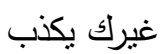

بنيّة السطح

ـ إفادة التخصيص وتقوّي الحكم:

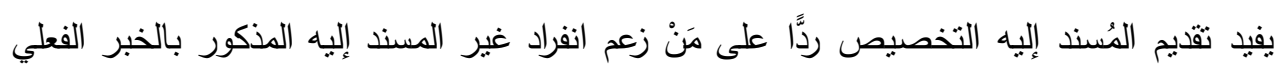

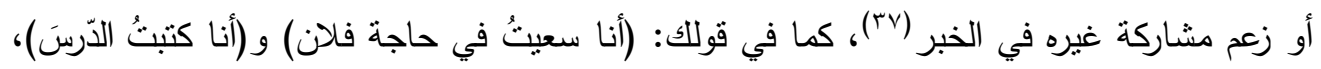

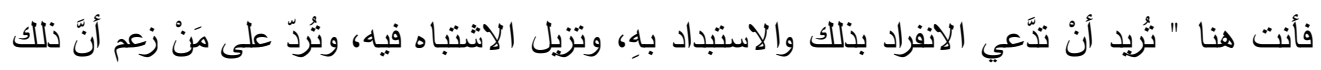

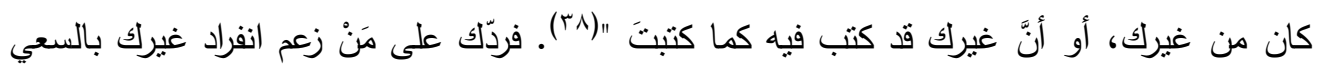

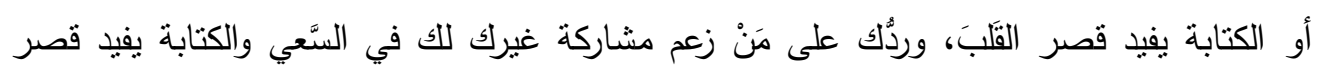

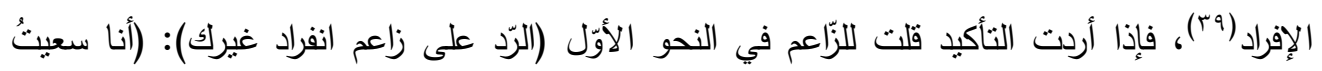

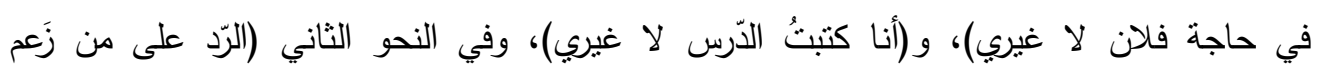

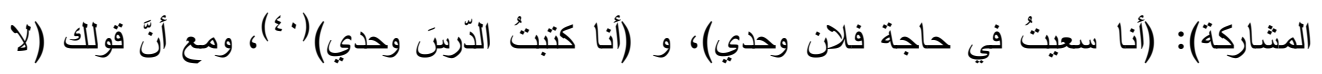

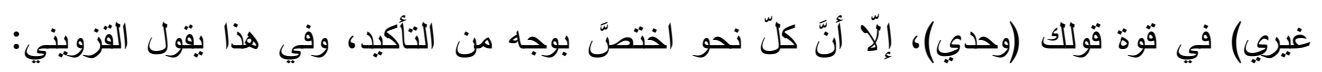

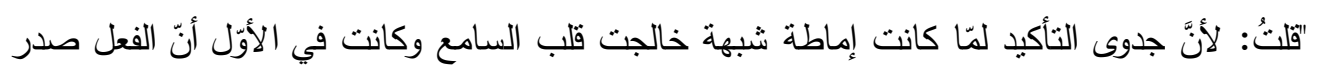

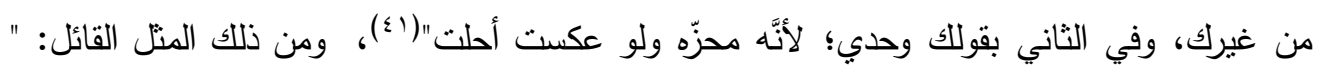

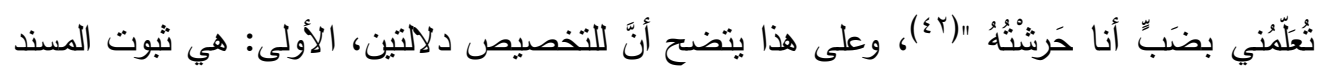


العـــــــــد السـابع والثلاثون

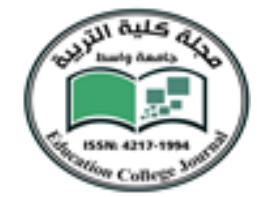

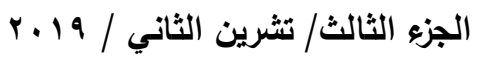
مجلـــــة كليــــة التربيــــة

لللمسند إليه، والثانية: هي نفيه عن غيره، وإفادة التخصيص في النماذج المنقدمة كانت "من نتائج

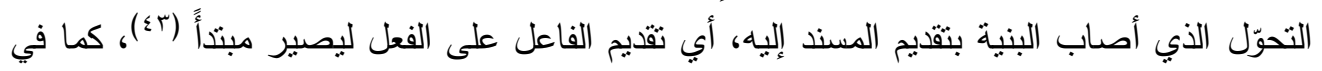
النحو الآتي: - n - n

بنية العقى (سعيثُ في حاجة فلان)، (كتبتُ الدَّرسَ)

فو(سعيثُ) جملة مؤلّفة من مسند (سعى) الذي هو الفعل، ومسند إليه (التاء) التي تعود على الفاعل،

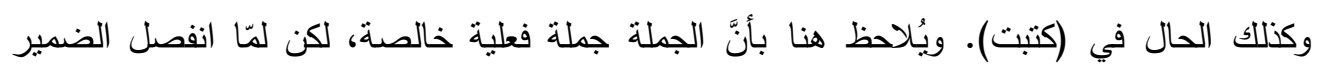

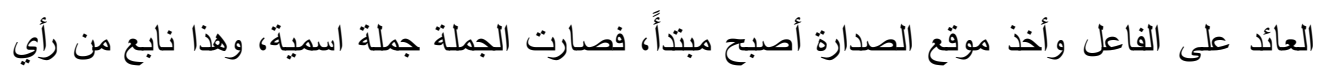

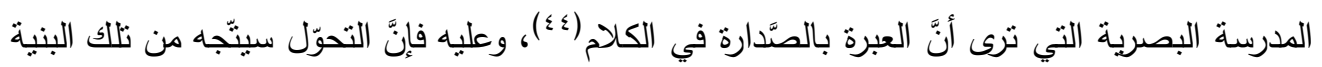

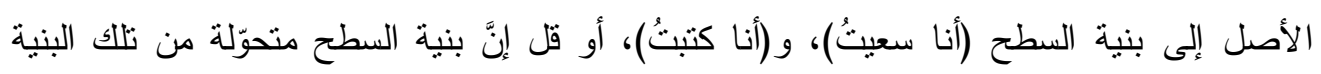
الأصل.

أمّا إفادة الثقوّي فقد ذكره الجرجاني بقوله: " أنْ لا يكون القصدُ إلى الفاعل على هذا المعنى، ولكن

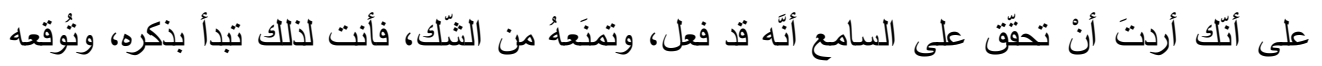

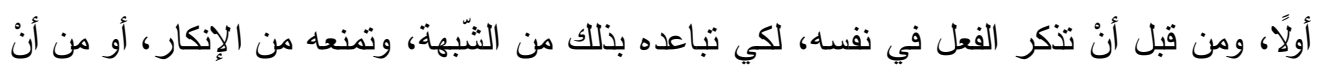

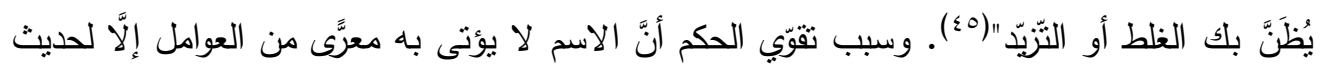

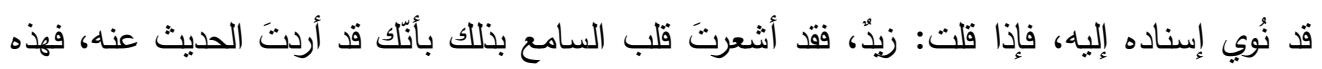

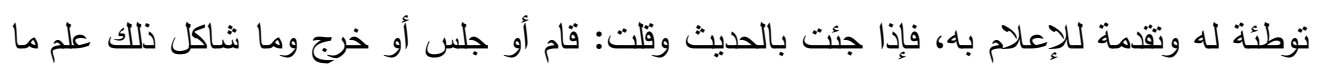

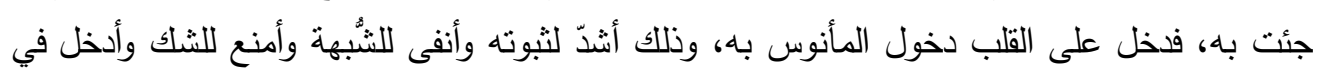
التحقيق، ومدار الأمر أنّه ليس إعلامك بالثيء بغتة منل الإعلام به بعد التتبيه عليه والتهيئة له؛

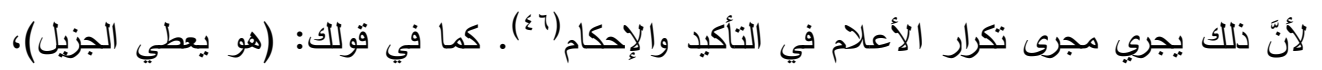

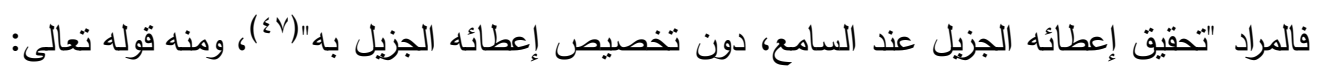

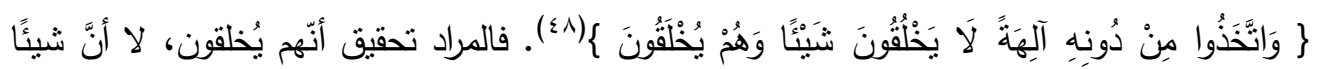

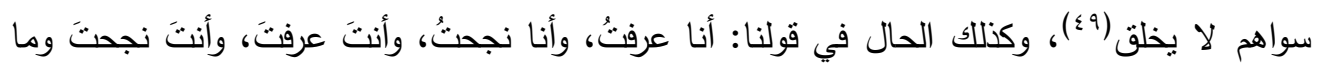
شابه ذللك. ويمكن النظر في كلام أبي يعقوب السكاكي لاستخلاص ما يتعلّق بإجراءات البنية العيقة

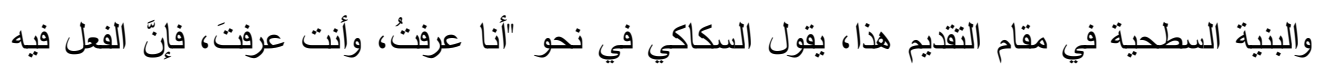

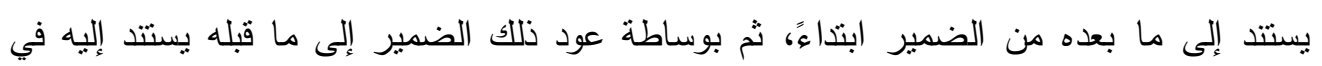


العـــــــــد السـابع والثلاثون

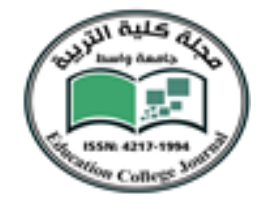

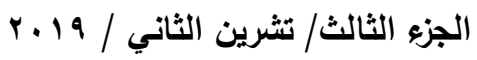

جامعة واسط

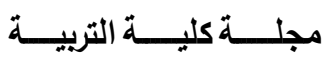

الدرجة الثانية"(•). وهذا من باب إسناد الثيء مرّتين، مّرة إلى الضمير المتّصل في (عرفتُ)، ومّرة

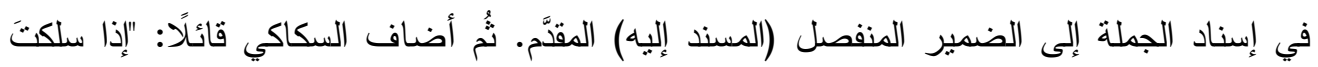

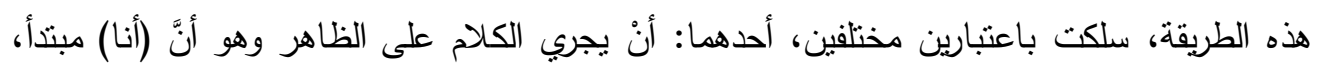

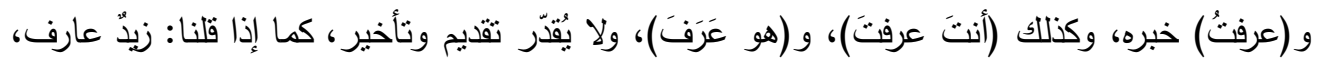

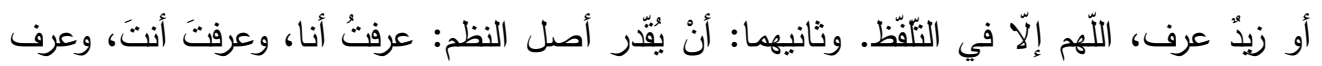

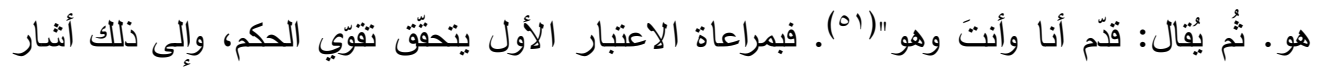

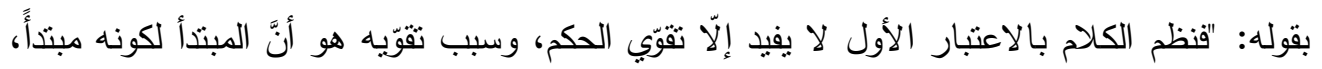

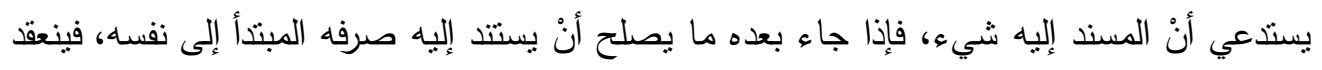

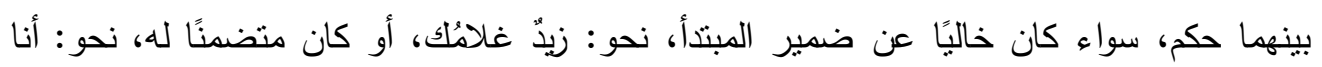

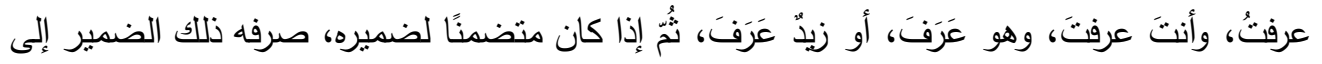

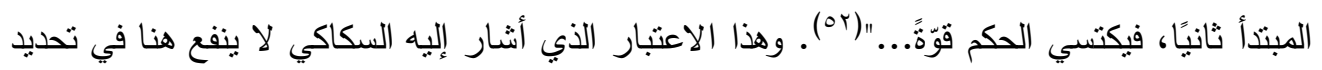

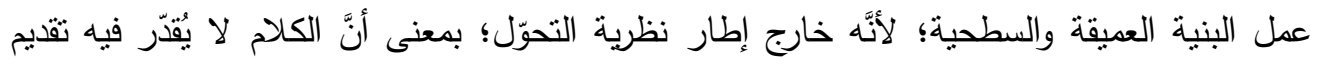

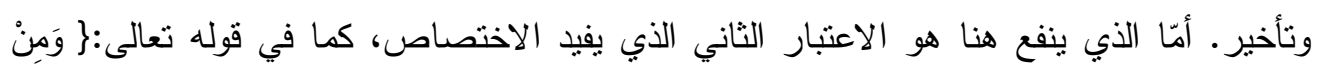

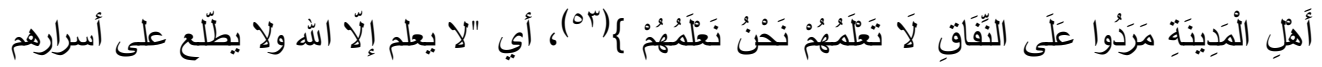

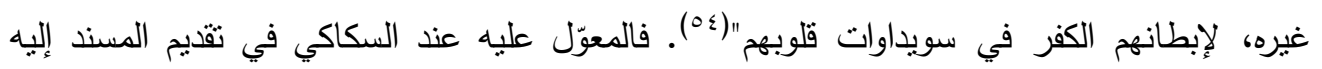

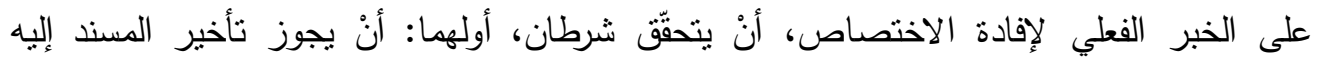

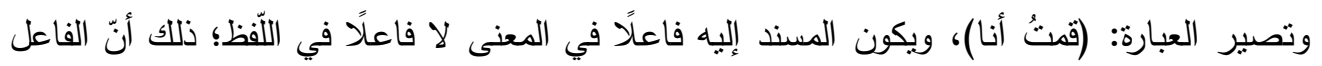

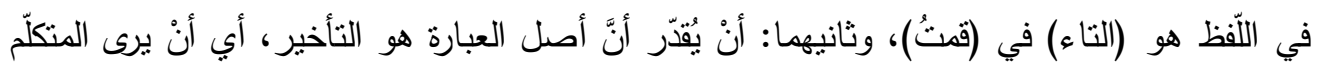

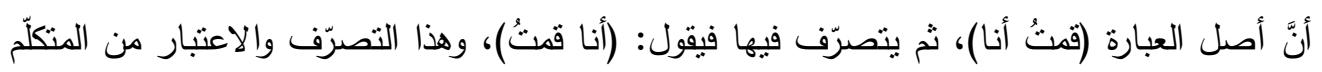

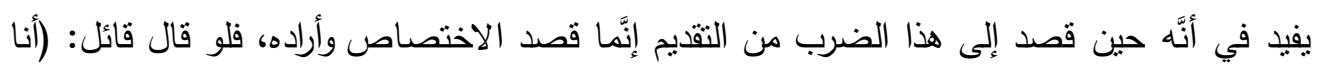

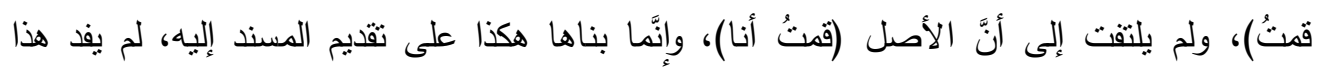

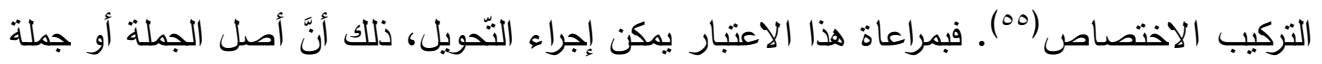

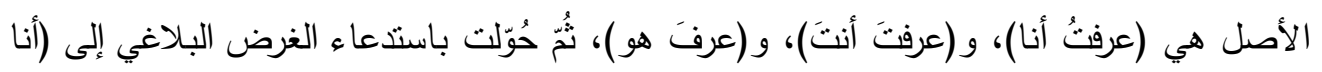

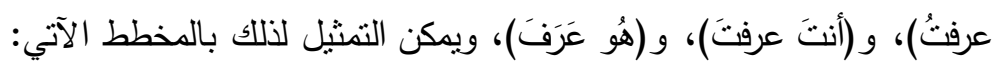


العــــــــد السـابع والثلاثون

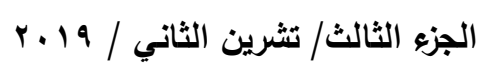

\section{1:}

جامعة واسط

مجلــــة كليــــة التربيــــة

عرفتُ أنا

بنية العمق

الأصل

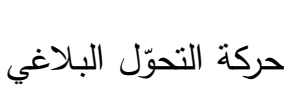

$\downarrow$

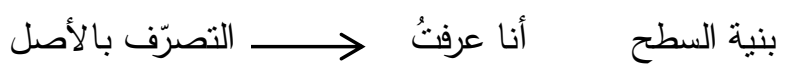

كان ما تقّم حديثٌ عن التقديم في سياق الإثبات، وهناك تقديم يجري في سياق النّفي، ويتوزع على صياغتين:

الأُولى: حرف النفي+ المسند إليه + المسند وهو فعل ما

وتقديم المُسند إليه في هذا السياق يفيد أمورًا ثلاثة (7ه):

1 - بفي الفعل عن المسند إليه المقّم.

r - إثبات نفس الفعل المنفي.

r - وجود فاعل غير المسند إليه المقّّم قد فعل الفعل.

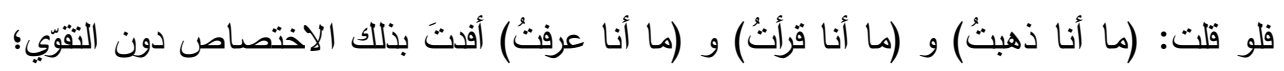

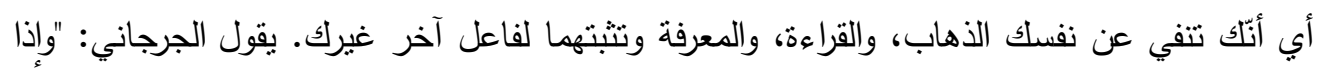

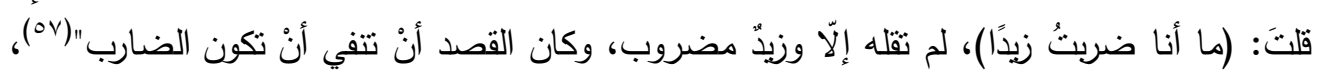

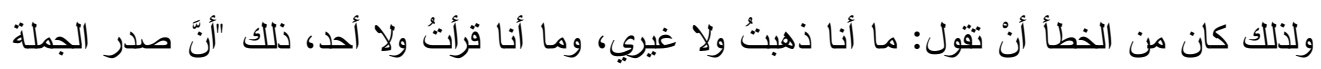

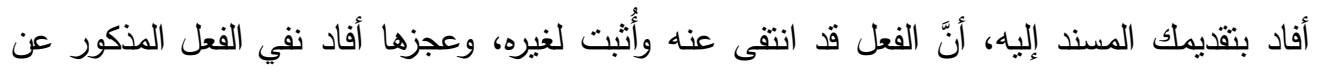

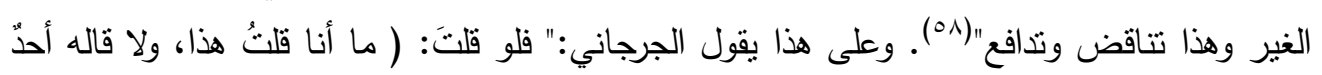

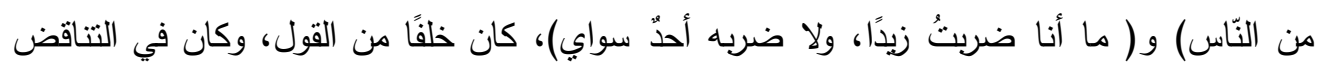

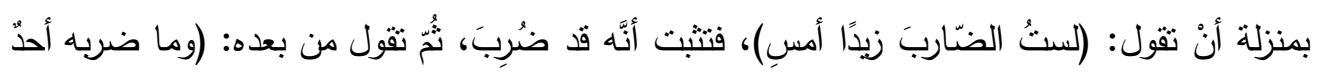

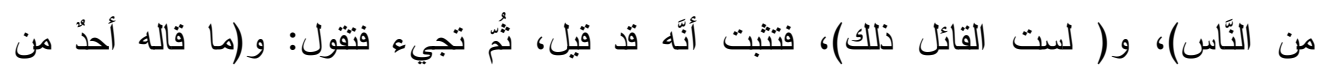

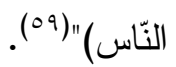


العــــــــد السـابع والثلاثون

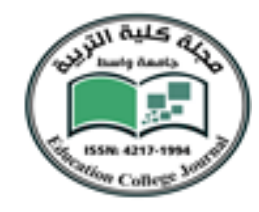

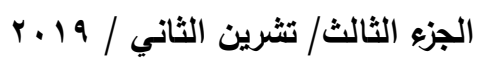

جامعة واسط

مجلـــــة كليـــــة التربيـــــة

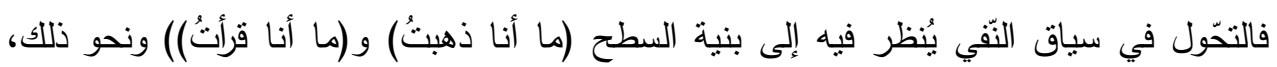

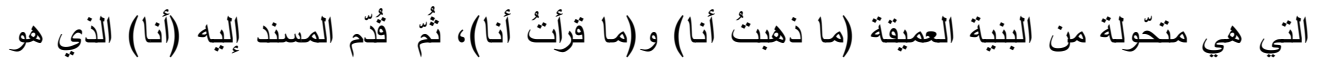
الفاعل في المعنى، في بنية السطح وصار مبنداً.

ومن ذلك قول المتتبي (·) (7)

ولا أنا أضرمثُ في القلب نارا وما أنا أسقتُ جسمي به

والمراد أنّ هذا السَّقم الحاصل في جسدي، وإضرام النيران في قلبي لم أفعلهما أنا، بل فعلهما أحدُ غيري(1). (1) (1)

ينتيّن ممّا تققّم أنَّ تقديم المسند إليه في هذه الصياغة يفيد الاختصاص قطعًا، وهذا ما ذهب إليه

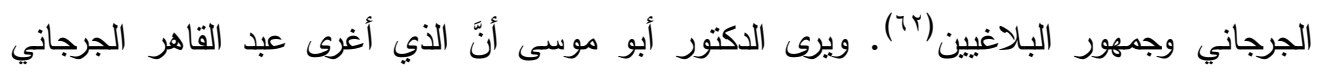

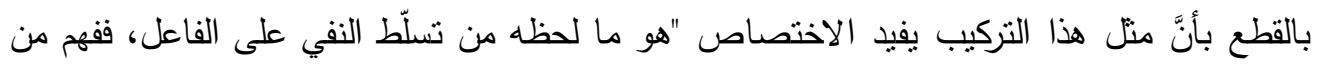

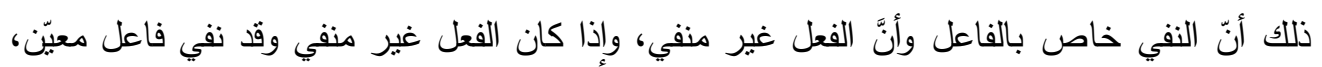

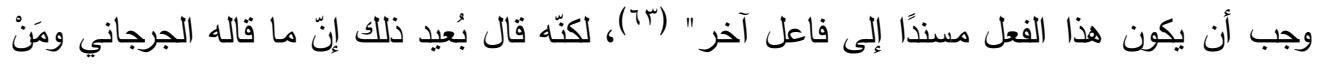

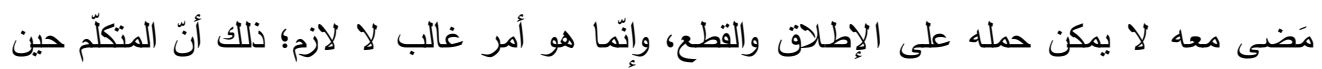

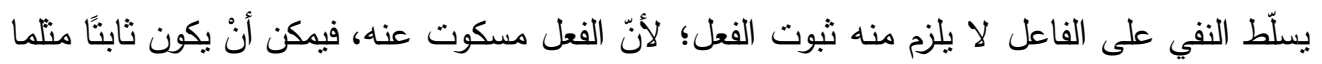

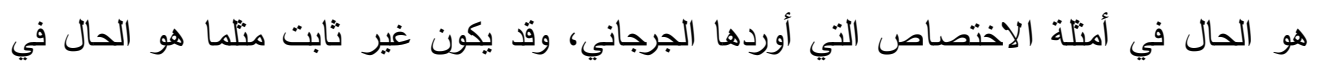

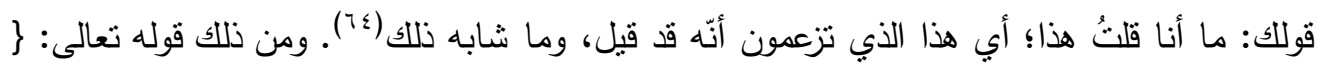

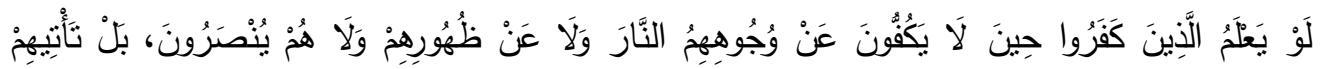

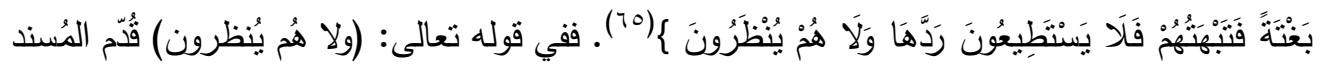

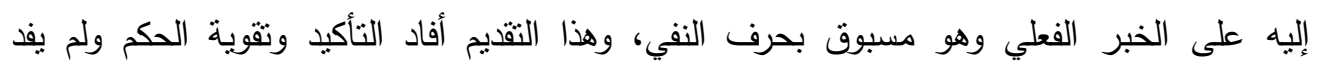

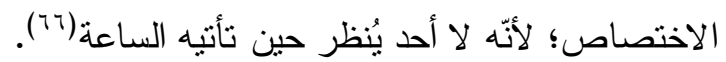


العـــــــــد السابع والثلاثون

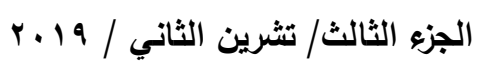

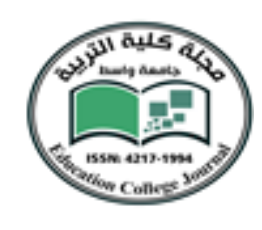

الثاتية: المسند إليه + حرف النفي + المُسند وهو فعل

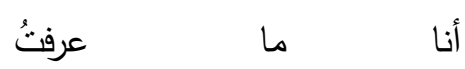

إذا تقدّم المسند إليه على أداة النفي أفاد ظلك التقوّي والتأكيد، وهو ظاهر من كلام الجرجاني إذ يقول: "وأعلم أنَّ هذا الصنيع يقتضي في الفعل المنفي ما اقتضاه في المُتتبت، فإذا قلتَّ: (أنتَ لاني تُحسنُ هذا)، كان أشنَّ لنفي إحسان ذلك عنها من أنْ تقول: (لا تُحسنُ هذا)، كان في الأوّل مَع مَن هو أثدُّ إعجابًا بنفسه، وأعرضُ دعوى في أنَّه يُحسن؛ حتّى إنّلك لو أتنت بـ(أنت) فيما بعدَ (تُحسن)

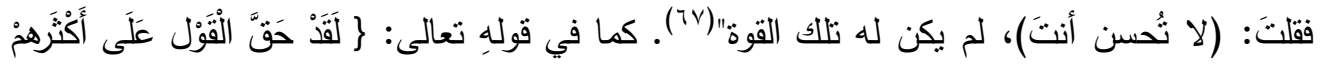

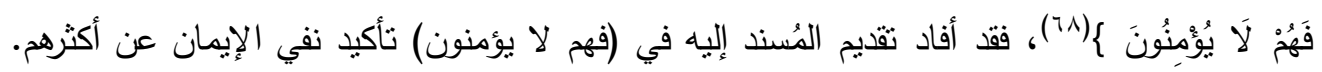
بيد أنَّ نقديم المسند إليه على أداة النفي لا يفيد التأكيد وتقوية الحكم فحسب، بل قد يفيد الاختصاص،

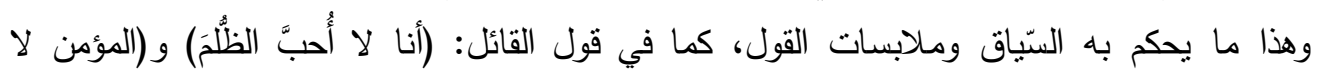
يسعى إلى الباطل)، إذا قصد نفي الفعل عن المسند إليه المقدم وأثثته لغيره(79). ويذكر أحد الباحثين

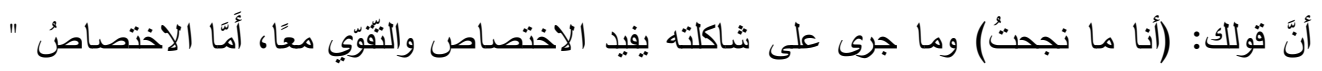
فلتقديم الفاعل، وأمّا التقوّي فلنفي النجاح عن المتكلّم مرّتين: فقولك: (ما نجحثُ) نفيُ للنجاح عن الفاعل، وقولك: (أنا نجحثُ) إثبات لعدم النجاح، وهو يؤدّي دور نفي النجاح"(•). ولو استحضرنا كلام السكاكي السابق حول التقديم والتأخير ، فقلنا: إنَّ أَصل الجملة (ما نجحتُ أَنا) لوجدنا أنَّها تمّتل بنية العمق، أمَّا قولك: (أنا نجحتُ) فإنَّها تمَّنل بنية السطح، وعلى هذا جرى التحّول من العمق إلى السطح بلحاظ استحضار الغرض البلاغي الذي قد يفيد التأكيد وتقوية الحكم، وقد يفيد الاختصاص، وقد يفيد الجمع بينهما. 
العـــــــــد السـابع والثلاثون

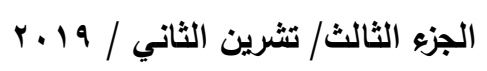

جامعة واسط

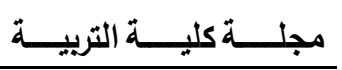

أمَّا عن الصياغات الأخرى التي لا يكون فيها المسند إليه منقّدمًا أو لا يكون المسند فعلًا، فتتوزّع على النحو الآتي (v) (vi):

$$
\begin{aligned}
& 1 \text { - حرف النفي + المُسند إليه + المُسند وهو اسم } \\
& \text { ما } \\
& \text { r - المُسند إليه + أداة النفي + المُسند وهو اسم }
\end{aligned}
$$

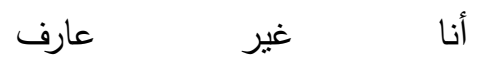

$$
\begin{aligned}
& \text { r- المُسند إليه + المُسند وهو اسم عُير }
\end{aligned}
$$

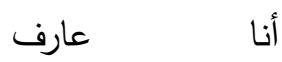

$$
\begin{aligned}
& \text { ع - المُسند وهو فعل + المُسند إليه }
\end{aligned}
$$

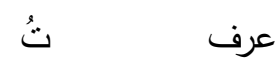

$$
\begin{aligned}
& \text { 0 - حرف النفي + المُسند وهو فعل + المُسند إليه }
\end{aligned}
$$

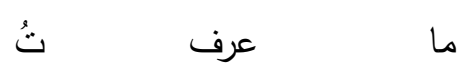

وهذه الصياغات جميعًا لا تفيد اختصاصيًا ولا ثقويةً، فأمّا عدم إفادة الاختصاص فلأنَّ البنية في

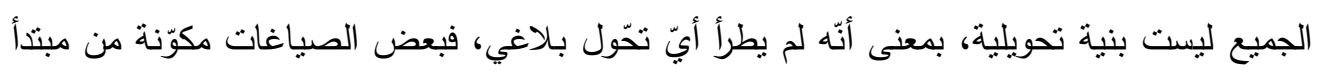
مقدّم وخبر مؤخّر، وهذا هو أصل الجملة قبل طروء أبيّ تحويل، ولا يكون تقديم المبتدأ تحويليَّا إلّا إذا مبان

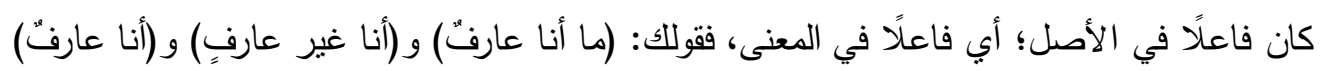
جاءت على أصل النظام اللغوي من دون تحويل. أمّا الصياغة الرّابعة وكذلك الخامسة فقد تقدّم فيها الفعل على الفاعل، وهذا جارٍ على أصل الكلام أيضًا.

هذا عن عدم إفادة الاختصاص، أمّا عدم إفادة الثقوّي فيعود إلى عدم وجود إثبات مرّتين، أو نفي

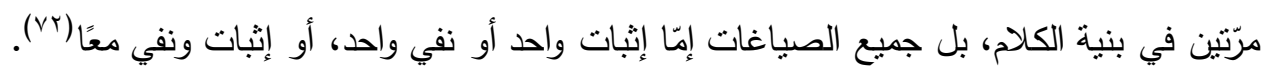

\section{إفادة سلب العموم أو عموم الستّلب:}

ممَّا بِلحق بهذا الباب تقديم النّفي على لفظ العدوم وتأخيره عنه، فإذا ما تقدّمت أداة النفي على لفظ العموم عُرف ذللك ب(سلب العموم)، كما في قول القائل: (لم أكتب كُلَّ ما ذكرتَ) و (ما كُلُّ النَّاس أقبلُوا). فسلب العموم أو الثَّمول يفيد ثبوت بعض ونفي بعض آخر • يقول الجرجاني:" وذلك أَنَّا إذا 
العـــــــــد السـابع والثلاثون

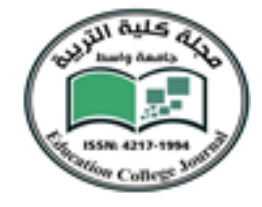

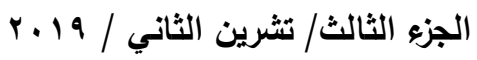

جامعة واسط مجلـــــة كليـــــة التربيـــــة

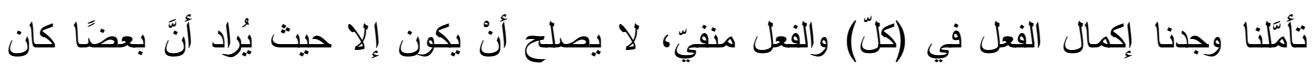

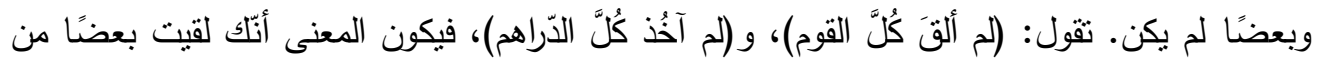

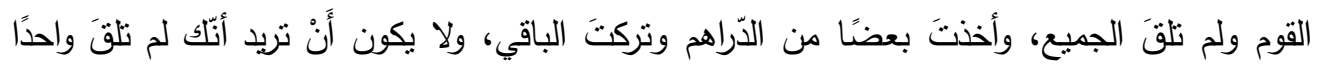

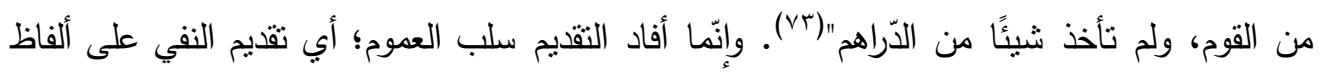

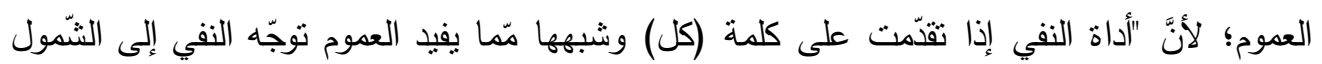

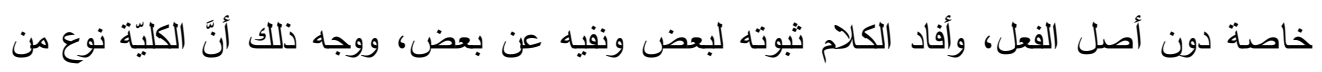

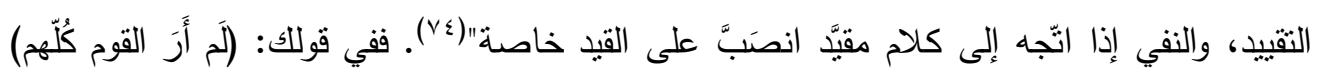

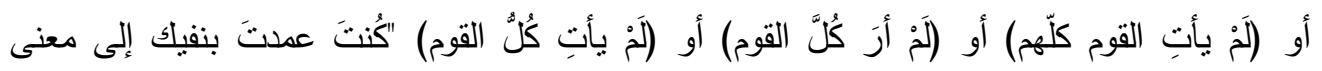

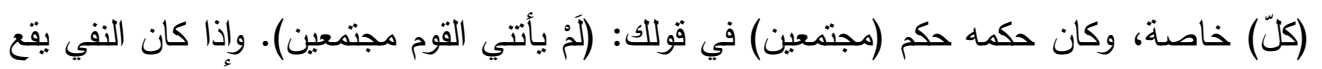

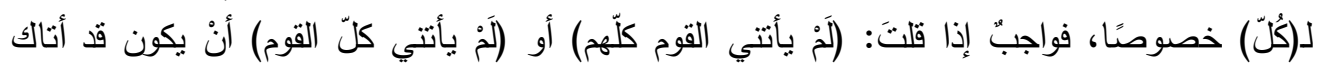

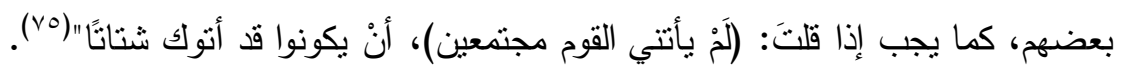

وما ذكره الجرجاني استخرك عليه التفتازاني، إذ ليس كلّ نفي تقّّم على ألفاظ العوم أفاد ما كان

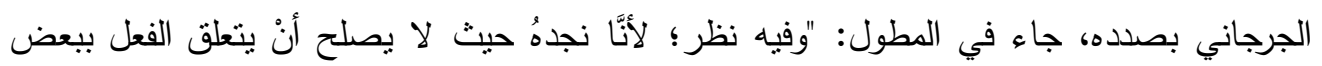

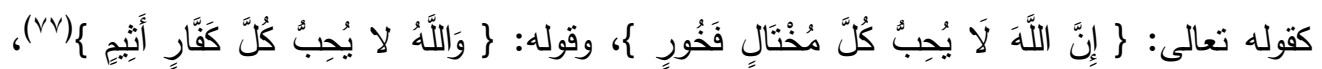

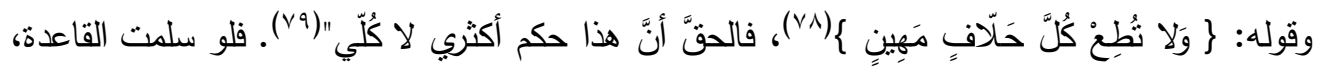

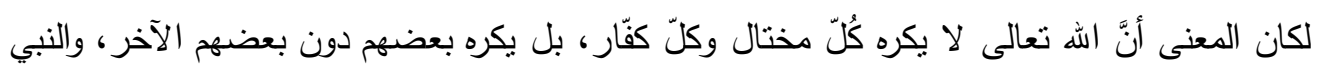

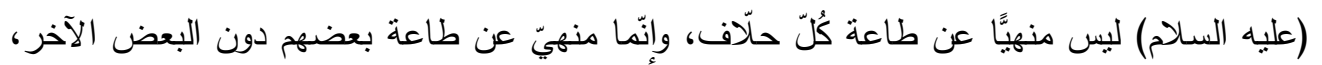

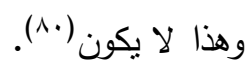

ذأمّا إذا تقدّم لفظ العموم على النّفي فهذا ما يُعرف بـ (عموم السّلب)، كما في قول القائل: (كلُّ ما

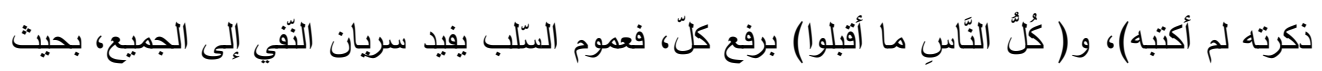

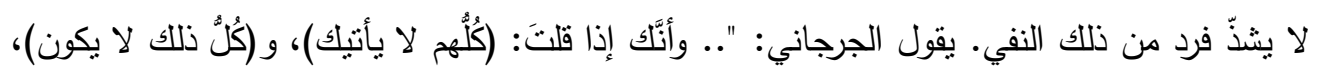

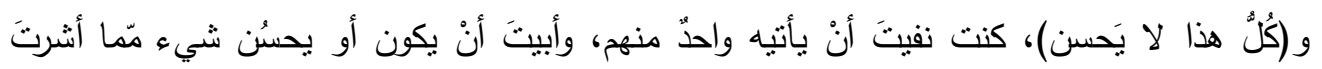

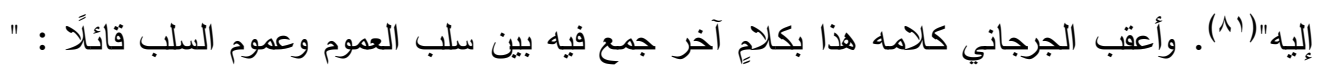

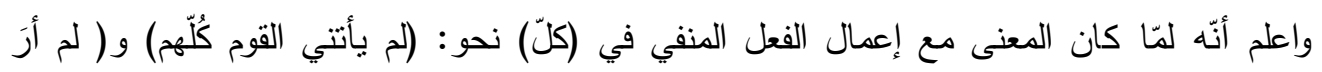

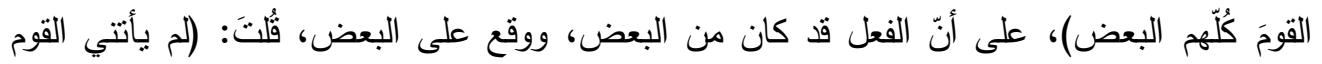


العــــــــد السـابع والثلاثون

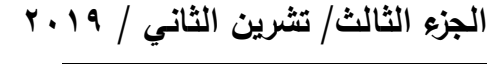

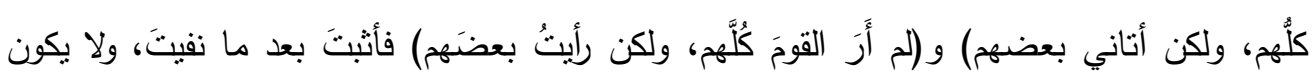

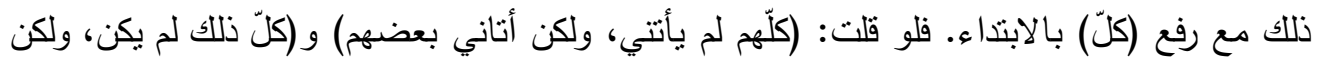

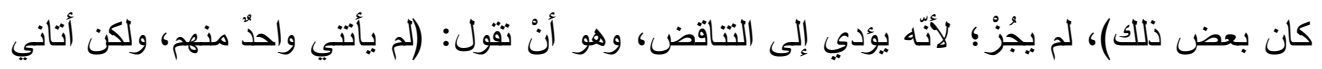

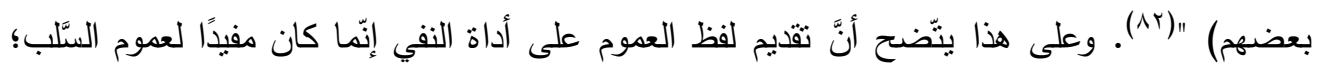

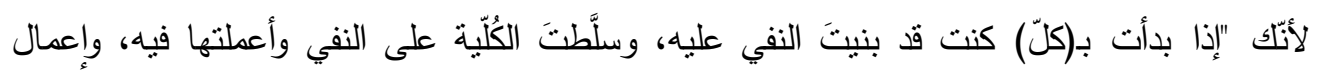

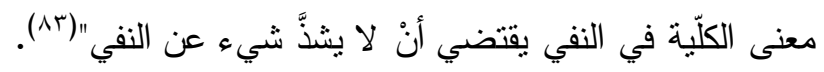

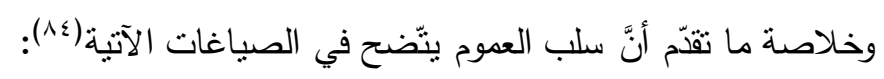
1 - أداة النفي + كلّ (المسند إليه)+ المُسند ما كُلٌُ النَّاس أقبلوا

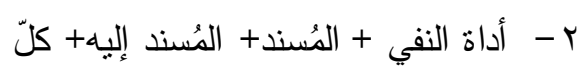

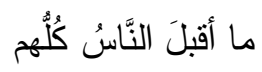

$$
\text { r- أداة النفي + المُسند+ كلّ (المُسند إليه) }
$$
ما أقبلَ كُلْ النَّاسِ

ويُمكن إجراء التحويل في سلب العموم لا بالنّظر إلى التقديم والتأخير، بل باستحضار دخول

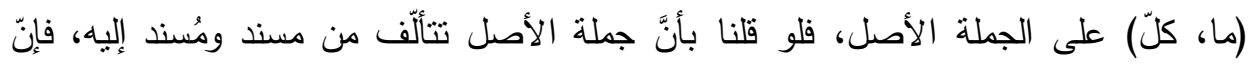

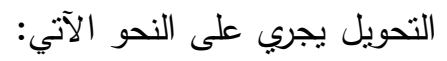
أل بنية العمق أقبلَ النَّاسُ بنية السطح لِّا أقبلَ النَّاسُ كُلُّهر ب/ بنية العمق أقبلَ النَّاسُ بنية السطح لما أقبلَ كُلْ النَّاسِ 
العــــــــد السـابع والثلاثون

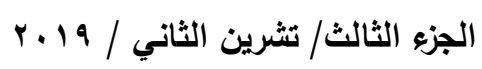

جامعة واسط مجلـــــة كليـــــة التربيــــــة

وبدخول (كلّ) أصبحت هي المُسند إليه، ومع هذا فإنَّ المُسند إليه في الجملة الأصل أصبح جزءًا من الصنا

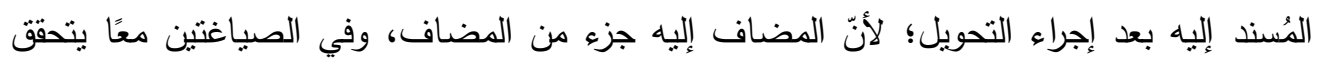
الغرض من التحوّل والمتمثل بـ(سلب العموم).

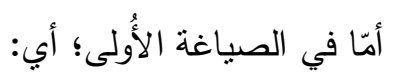
أداة النفي + كلّ (المُسند إليه)+ المُسند ما كُلُْ النَّاسِ أقبلوا

فيمكن أنْ نقول إنَّ جملة الأصل هي: كُلٌّ النَّاسِ أقبلوا المتكوّنة من مسند إليه ومسند، وبعد إجراء التحويل دخلت أداة النفي على صدر الجملة (ما كُلٌ النَّاسِِ أقبلوا )، فتحقق الغرض من التحويل أيضًا، والَّني يتّضح في (سلب العموم). ويُّلاحظ أنَّ الأمر في هذا الإجراء تعلّق بأداة النفي (ما) فحسب، ولَّمَ يشمل لفظ العموم (كلّ)؛ لأنَّ

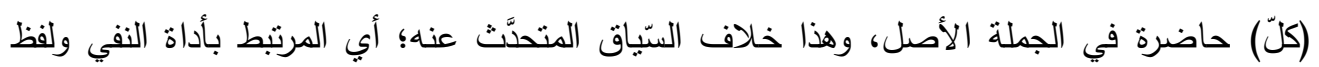
العموم. (- non

وعلى هذا يمكن افتراض أنّ الجملة الأصل مؤلفة من:

( النَّاسُ أقبلوا )

ثمّ جرى التحويل فصارت (ما كُلٌْ النَّاسِِ أقبلوا )، وقياساً على التحويل في (ب)، فإنَّ (كلّ) صارت

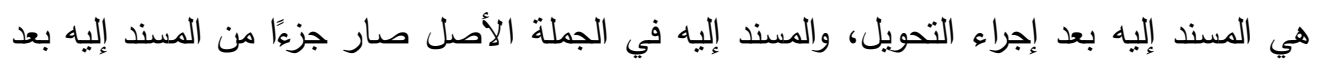

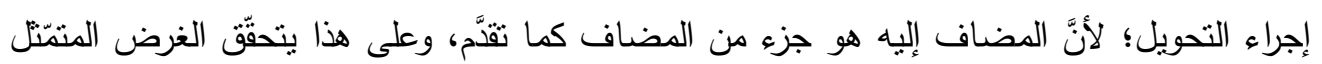

$$
\text { ب(سلب العموم). }
$$


العـــــــد السـابع والثلاثون

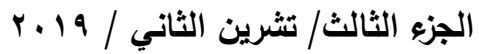
مجلـــــة كليـــــة التربيـــــة

أمَّا عموم السّلب فله صياغة واحدة هي: كلّ (المسند إليه)+ أداة النفي+ المسند

كُلْ النَّاسِ ما أقبلوا

وهنا - أيضًاًا - يمكن افتراض أنَّ جملة الأصل: (النَّاس أقبلوا) المؤلفّة من المسند إلبه والمسند، وبعد إجراء التحويل صـارت: (كلّ النّاس ما أقبلوا)، فتحقّق الغرض المتمّتل ب(عموم السلب).

ويمكن افتراض أنَّ جملة الأصل: (كُلّ الناسِ أقبلوا)، المؤلّفة من المسند إليه (كلّ) وما أُضيف إليه،

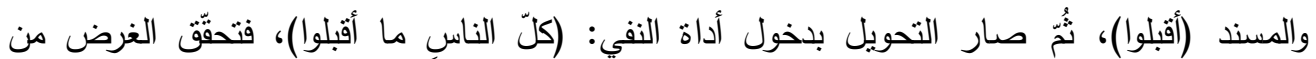
التحويل ألا وهو (عموم السلب). والافتراض الأول أقرب، لأنَّ المتحدّث عنه يشمل أداة النفي وألفاظ العموم. 
العـــــــــد السابع والثلاثون

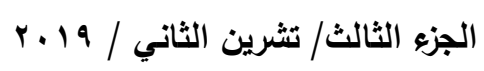

جامعة واسط

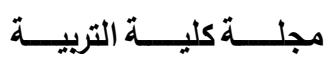

المصادر والمراجع:

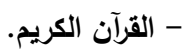

- الانزياح من منظور الدراسات الأسلوبية، د. أحمد محد ويس، ط: ا، المؤسسة الجامعية للاراسات والنشر والتتوزيع،

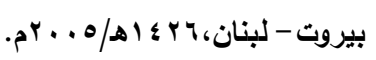

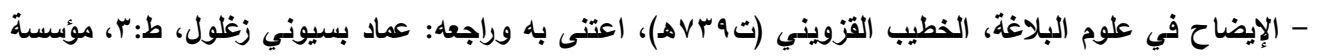
الكتب الثقافية، بيزوت - لبنان، د.ت.

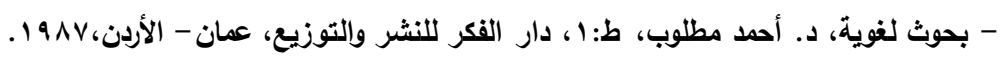

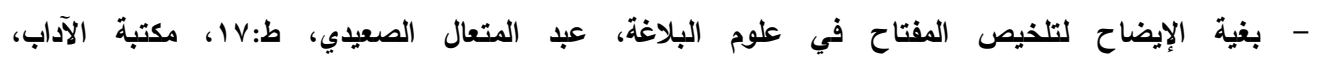

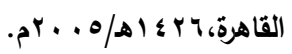
- البلاغة العربية قراءة أخرى، د. محمد عبد المطل، ط:؟، الثركة المصرية العالمية للنشر، لونجمان، مصر، 199V

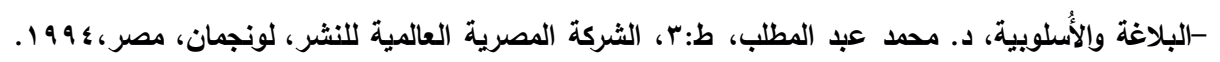

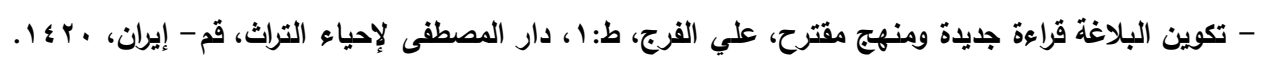

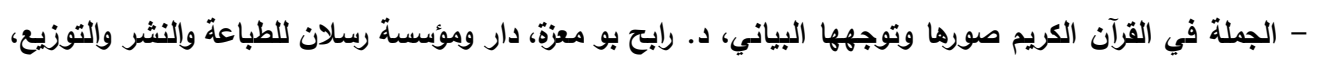

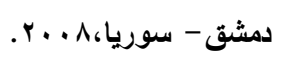

- خصائص التراكيب دراسة تحليلية لمسائل علم المعاني، د. دمد مد محد أبو موسى، ط:9، مكتبة وهبة،

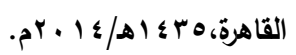

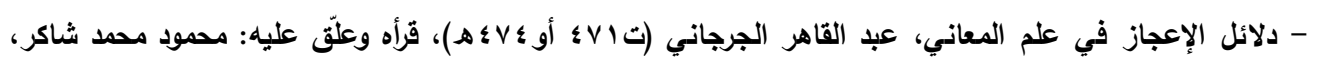

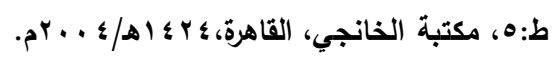

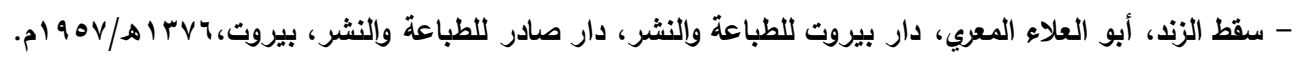

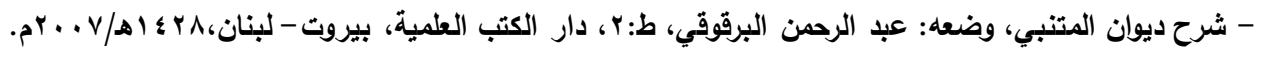

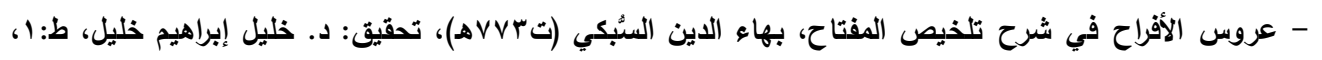

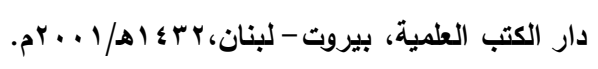

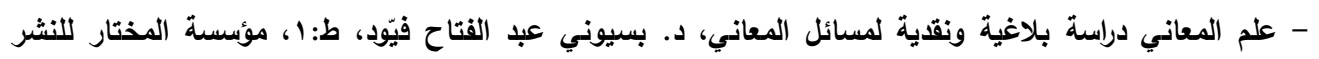

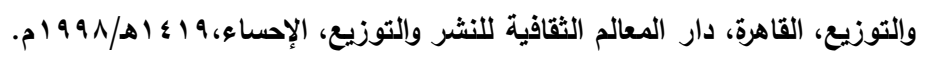

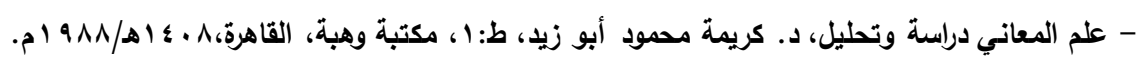

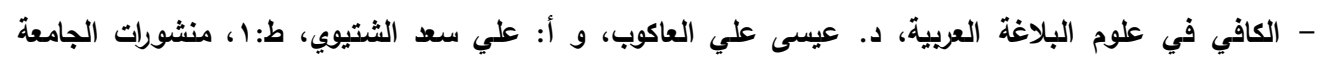

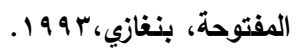
- اللغة والإبداع، مبادئ علم الأسلوب العربي، شكري عيّاد، ط:ا، التنوير للطباعة والنشر والتوزيع، بيروت-

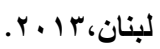


العـــــــــد السـابع والثلاثون

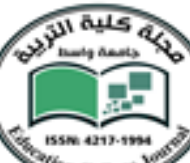

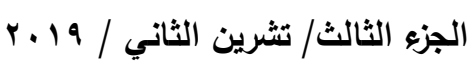

جامعة واسط

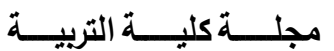

- مجمع الأمثال، أبو الفضل أحمد بن محمد الميداني (ت1/0هـ)، تحقيق: محمد محيي الدين عبد الحميد، مطبعة

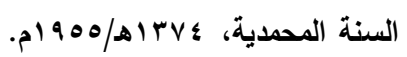

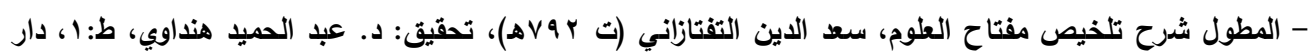

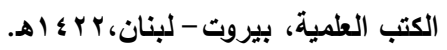

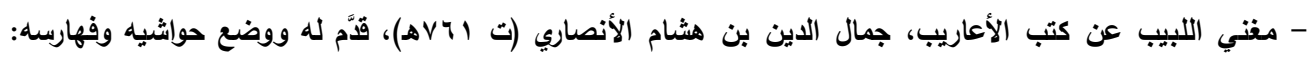

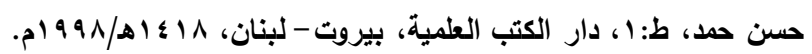

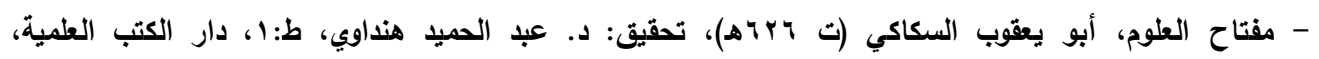

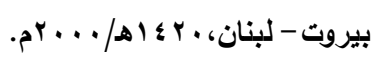

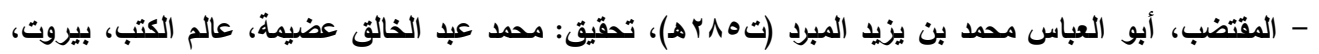
د.ت. - من بلاغة النظم العربي، دراسة تحليلية لمسائل المعاني، د. عبد العزيز عبد المعطي عرفة، ط:؟، عالم الكتب،

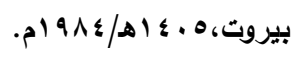
- منهج البحث اللغوي بين التراث وعلم اللغة الحديث، د. علي زوين، ط: 1، دار الثؤون الثقافية، بذاد، 1914.

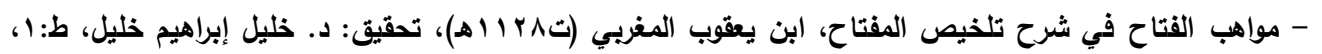

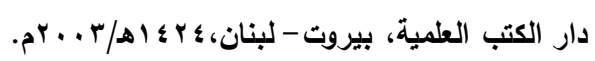

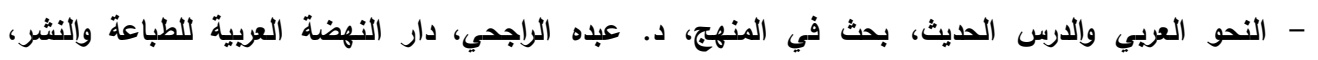

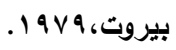


العـــــــــد السـابع والثلاثون

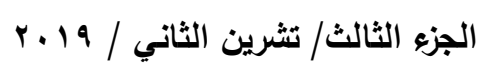

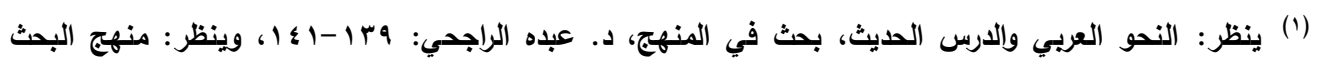

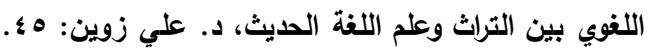

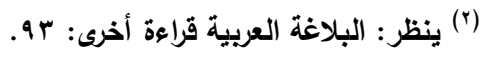

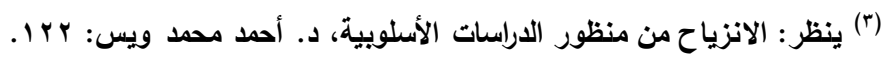

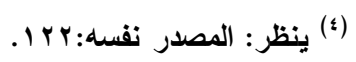

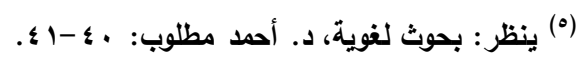

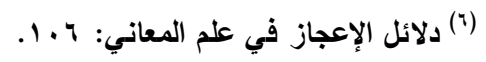

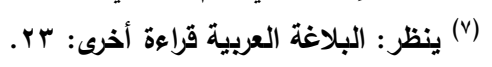

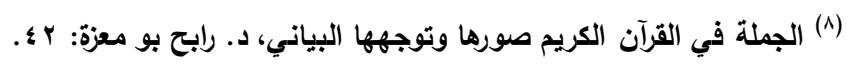

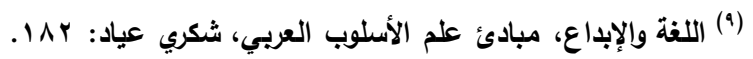

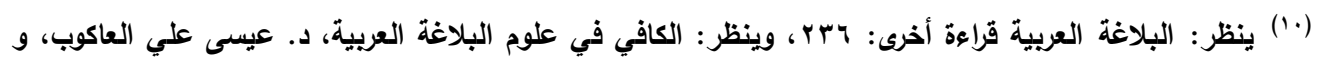

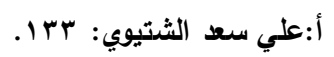

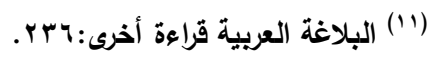

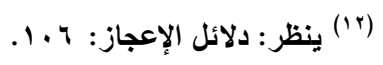

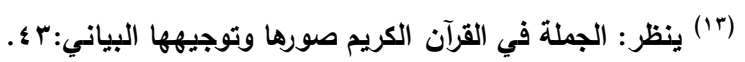

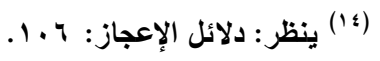

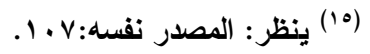

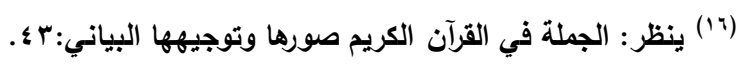

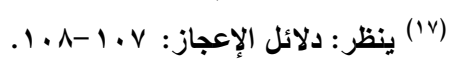

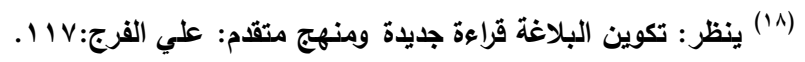

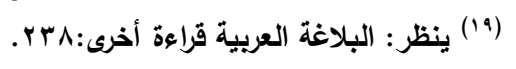

(r.r) ينظر: الإيضاح في علوم البلاغة، الخطيب القزويني:^r،، وينظر: من بلاغة النظم العربي، د. عبد العزيز

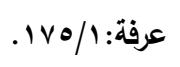

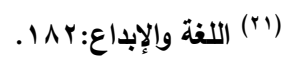

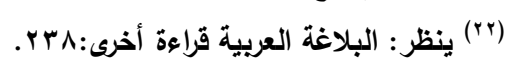

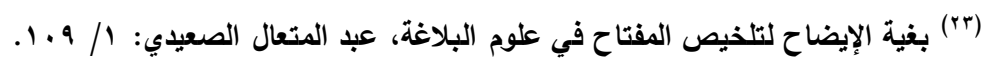

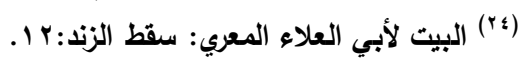

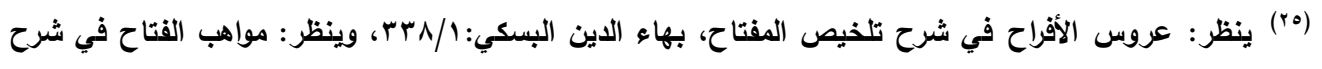

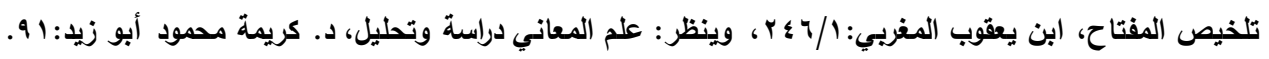
(ז' ينظر: تكوين البلاغة: 111. 
العـــــــد السـابع والثلاثون

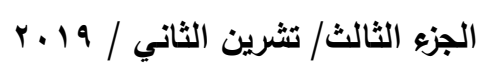

جامعة واسط

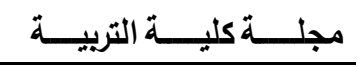

(المصدر نفسه:(rv)

(r^)

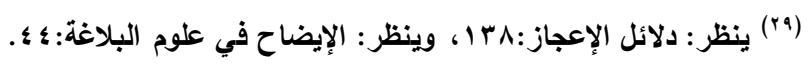

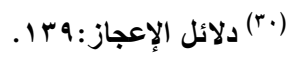

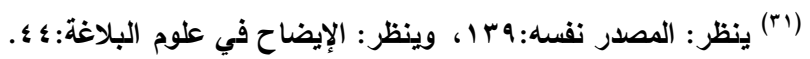

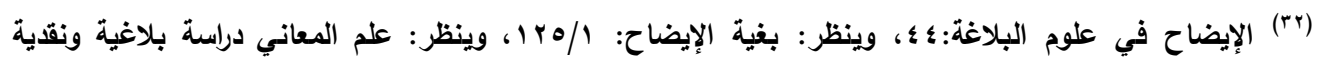

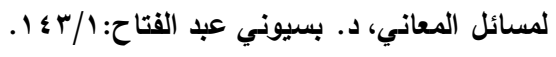

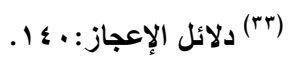

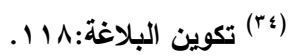

(ro)

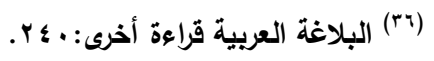

(rv)

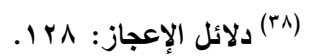

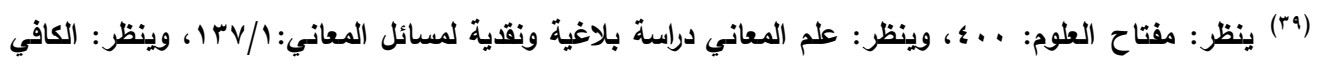

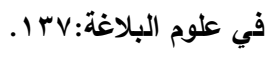

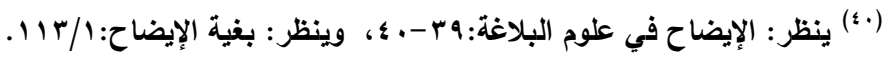

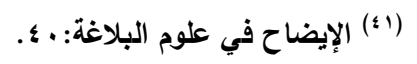

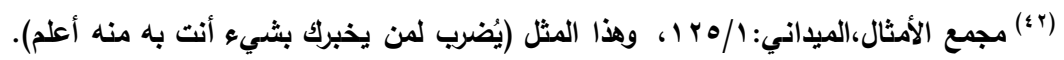

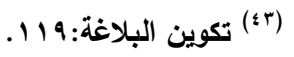

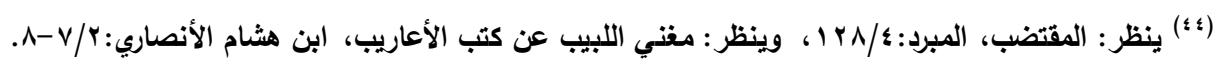

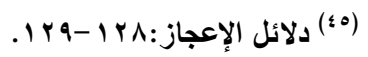

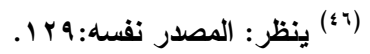

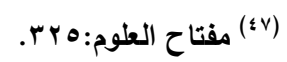

(الفرقان:r)

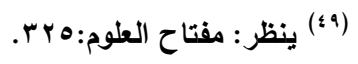

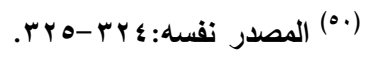

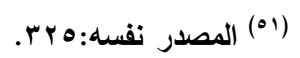

(المصدر نفسه:Pror)

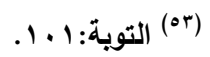

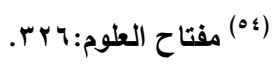

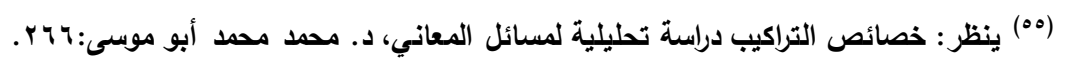

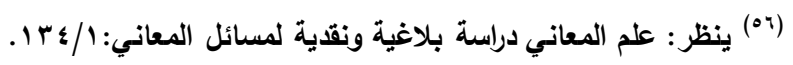


العـــــــــد السـابع والثلاثون

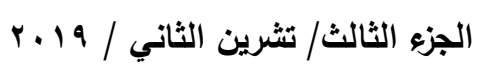

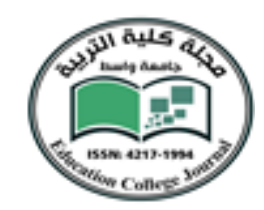

جامعة واسط

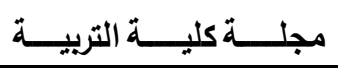

(OV)

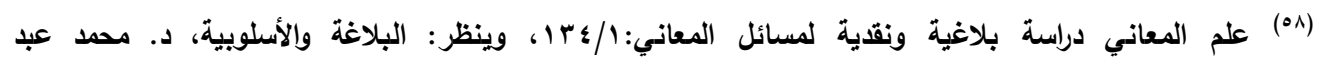

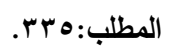

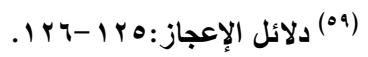

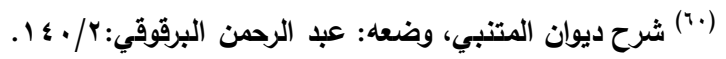

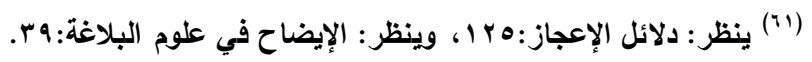

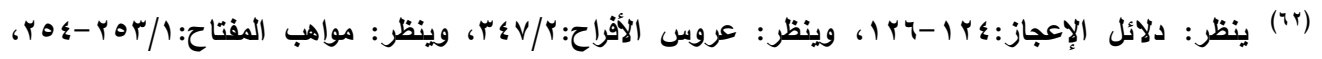

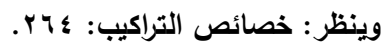
(r)

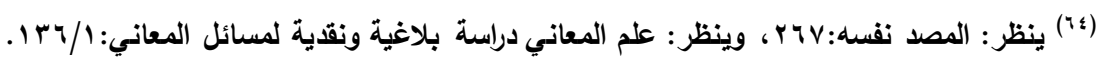

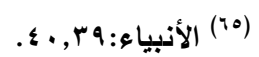

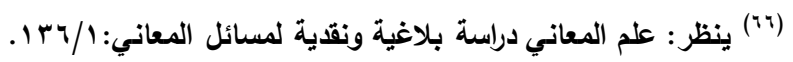
(IV)

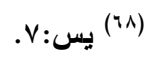

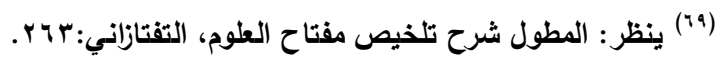

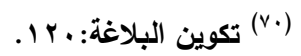

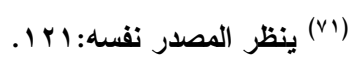
(Vr)

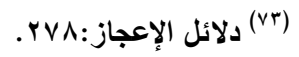

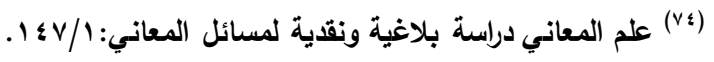

$$
\begin{aligned}
& \text { (vo) }
\end{aligned}
$$

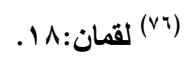

$$
\begin{aligned}
& \text { (البقرة: (vv) } \\
& \text { (v^) }
\end{aligned}
$$

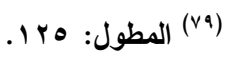

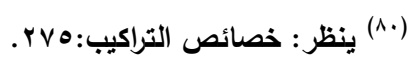

$$
\begin{aligned}
& \text { ( المائل }
\end{aligned}
$$

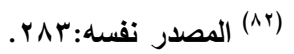

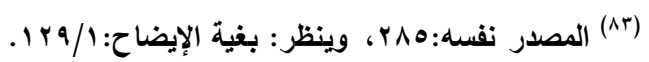

$$
\begin{aligned}
& \text { (^) }
\end{aligned}
$$

